Article history:

Received: 15 January 2020;

Revised: 31 January 2020;

Accepted: 15 February 2020;

Available online: 24 February 2020

\title{
Analisis Perkembangan Usaha Mikro, Kecil dan Menengah (Umkm) Sebelum dan Sesudah Memperoleh Pembiayaan dari Lembaga Keuangan Syariah (Studi Kasus UMKM Kabupaten Bandung)
}

\author{
Budi Rustandi Kartawinata ${ }^{1}$, Candra Wijayangka ${ }^{2}$, Hanansa R.Dabinda ${ }^{3}$, Salma Aprilia ${ }^{4}$ \\ Prodi S1 Administrasi Bisnis, Fakultas Komunikasi dan Bisnis, Universitas Telkom \\ budikartawinata@telkomuniversity.ac.id
}

\begin{abstract}
This research was conducted to determine the development of Micro, Small and Medium Enterprises (MSMEs) before and after obtaining financing from syariah financial institutions (case study: MSMEs around the Dayeuhkolot market). This study uses a quantitative method with a type of descriptive-comparative research. Sampling is done by non-probability sampling method type of proporsive sampling, with the number of respondents as many as 30 people. The data analysis technique is used descriptive analysis. Based on the results of testing the hypothesis significantly, the development of MSMEs around the Dayeuhkolot market experienced significant differences before and after obtaining financing from syariah financial institutions. This is evidenced by $z$ count $\geq z$ table, namely for the dimension of sales turnover is $4.794 \geq 2.042$, the dimension of labor is $4.673 \geq 2.042$, and the customer dimension is $4.766 \geq 2.042$ with a significance level of 0.000 $<0.05$. Conclusion of this study, the development of MSMEs on the dimensions of sales turnover fall into the very good category, in the dimensions of labor included in the category quite well, and on the dimensions of the customer included in the fairly good category.
\end{abstract}

Keywords: development of MSMEs, sales turnover, labor, customers, financing

\section{Pendahuluan}

Ketika krisis ekonomi menerpa dunia, otomatis memperburuk kondisi ekonomi di Indonesia. Kondisi krisis terjadi priode tahun 1997 hingga 1998, hanya sektor UMKM (Usaha Mikro Kecil dan Menengah) yang mampu tetap berdiri kokoh. Data Badan Pusat Stastistik merilis keadaan tersebut pasca krisis ekonomi jumlah UMKM tidak berkurang, justru meningkat pertumbuhannya teruas, bahkan mampu menyerap 85 juta hingga 107 juta tenaga kerja sampai tahun 2012. Pada tahun itu jumlah pengusaha di Indonesia sebanyak 56.539.560 unit. Dari jumalh tersebut, UMKM sebanyak 56.534.592 unit atau sebesar 99,99\%. Sisanya sekitar 0,01\% atau sebesar 4.968 unit adalah Usaha bersekala besar.

Kontribusi UMKM dalam perekonomian Indonesia adalah UMKM menjadi prioritas nasional dalam percepatan pembangunan. UMKM menjadi prioritas nasional karena dapat menyerap tenaga kerja dalam jumlah yang cukup banyak dan menciptakan banyak lapangan pekerjaan sehingga

${ }^{1}$ Korespondensi: Budi Rustandi Kartawinata. Universitas Telkom. Jl. Telekomunikasi No.1 Bandung. (022) 7564108. budikartawinata@telkomuniversity.ac.id 
dapat mengurangi pengangguran (Muhril, 2014, p. 15). UMKM dapat menjadi salah satu solusi atas pengangguran yang ada di Indonesia.

Fenomena ini menjelaskan bahwa UMKM merupakan usaha yang produktif untuk dikembangkan bagi mendukung perkembangan ekonomi secara makro dan mikro di Indonesia dan mempengaruhi sektor-sektor yang lain bisa berkembang. Salah satu sektor yang terpengaruh dari pertumbuhan UMKM adalah sektor jasa perbankan yang ikut terpengar, sebab hampir 30\% usaha UMKM mengunakan modal oprasioanal dari perbankan. Pengalaman tersebut telah menyadar kan banyak pihak, untuk memberikan porsi lebih besar terhadap bisnis skala mikro, kecil, dan menengah. Persoalan klasik seperti akses permodalan kepada lembaga keuangan pun mulai bisa teratasi. Karena di dalam peraturan itu tercantum mengenai perluasan pendanaan dan fasilitasi oleh perbankan dan lembaga jasa keuangan non-bank (LPPI\&BI,2015:1).

Ada beberapa masalah yang umum dihadapi oleh pengusaha kecil dan menengah seperti keterbatasan modal kerja, modal investasi, kesulitan mendapatkan bahan baku dengan kualitas yang baik dan harga terjangkau, keterbatasan terknologi, sumber daya manusia dengan kualitas yang baik (manajemen dan teknik produksi), informasi pasar serta kesulitan dalam pemasaran. (Tambunan, 2002, p. 73).

Seperti hal nya masalah yang terjadi di Dayeuhkolot, Kab. Bandung, bencana banjir yang terjadi membuat perekonomian warga menjadi lumpuh. Sebab, banjir merendam kios-kios dan toko-toko warga, seperti yang terjadi di pusat pertokoan Pasar Dayeuhkolot. Para pedagang terpaksa menutup kios-kios dan toko-toko mereka. Tutupnya tempat usaha mereka membuat mereka menjadi tidak ada pemasukan selama berminggu-minggu. Mereka mengalami kerugian hingga ratusan juta rupiah. Banjir juga merendam pabrik-pabrik di Bandung Selatan. Pabrik-pabrik terpaksa tuutp dan menghentikan aktivitas produksi. Kondisi tersebut berpotensi membuat pabrik gulung tikar. Sedangkan, Bandung Selatan merupakan sentra industri yang menopang perekonomian Jawa Barat. Bukan tidak mungkin, produsen akan memilih memindahkan lokasi pabrik mereka, apalagi jika Dayeuhkolot menjadi daerah yang sering terkena banjir. Agar perekonomian kembali normal pascabanjir, pemerintah daerah perlu memberikan suntikan dana kepada para petani dan pengusaha yang mengalami kerugian. Dana diperlukan untuk menutup kerugian serta dipakai untuk modal memulai kembali usaha mereka yang sempat terhenti.

Fungsi perbankan sebagai lembaga intermediasi keuangan juga menjadi concern dari perbankan syariah, disamping sebagai lembaga yang mengelola zakat, infak, dan sedekah (ZIS). Eksistensi perbankan syariah di Indonesia mengalami perkembangan yang signifikan setelah diundang kannya (Undang-undang Nomor 10 Tahun 1998 tentang perubahan Undang-undang Nomor 7 Tahun 1998 tentang Perbankan). tentang perbankan yang lebih mengakomodasi dan memberi peluang bagi perkembangan perbankan syariah. Kehadiran undang-undang tersebut di perkuat lagi dengan lahirnya (Undang-undang Nomor 21 Tahun 2008 tentang Perbankan Syariah), yang secara tegas mengakui eksistensi dari perbankan syariah dan membedakannya dengan sistem perbankan konvensional.

Berdasarkan peraturan Bupati Bandung Nomor 38 Tahun 2010 Tentang Teknis Pembiayaan Usaha Mikro-Kecil Melalui Lembaga Keuangan Mikro Non Perbankan di Kabupaten Bandung pasal 2 mengenai tujuan dan sasaran pembiayaan mikro-kecil. Tujuan pembiayaan Mikro-Kecil dengan penyediaan dana permodalan adalah dalam rangka mengedepankan peran sentral SKPD Pemerintah Kabupaten Bandung yang bertugas pokok membina koperasi, usaha mikro, kecil dan menengah dan SKPD yang terkait dengan program Pemerintah di bidang perindustrian, perdagangan, pertanian, perkebunan, peternakan dan perikanan, skema ini merupakan katalisator program-program perintah yang diusung oleh SKPD yang terkait.

Untuk melihat perkembangan usaha ada beberapa indikator yang digunakan, yaitu omset penjualan, jumlah tenaga kerja, dan pertumbuhan jumlah pelanggan. Omset penjualan menunjukkan dengan adanya tambahan modal dapat meningkatkan produksi atau menambah 
barang dagangan untuk meningkatkan jumlah penjualan. Bila produksi meningkat tentunya membutuhkan lebih banyak tenaga kerja. Setelah adanya produksi yang meningkat menjadikan pertumbuhan jumlah pelanggan yang lebih banyak.

\section{Literature Review}

\section{Pengertian UMKM (Usaha Mikro, Kecil dan Menengah)}

Pengertian Usaha Mikro

Menurut Undang-Undang Republik Indonesia Undang-undang Nomor 20 Tahun 2008, usaha mikro merupakan usaha produktif milik perorangan atau individu, atau badan usaha perorangan yang memenuhi kriteria usaha mikro sebagai berikut:

a. Memiliki kekayaan bersih maksimal 50 juta rupiah selain tanah dan bangunan tempat usaha.

b. Mendapatkan hasil penjualan maksimal 300 juta rupiah (nilai nominal ini bisa berubah sesuai dengan perkembangan ekonomi yang diatur oleh Peraturan Presiden).

\section{Pengertian Usaha Kecil}

Usaha kecil merupakan usaha ekonomi produktif yang dilakukan oleh orang perseorangan, yang tidak menjadi bagian dari usaha menengah ataupun usaha besar, serta memenuhi kriteria usaha kecil yang tercantum dalam undang-undang yaitu:

a. Memiliki kekayaan bersih Rp 50.000.000,- dengan maksimal yang dibutuhkannya mencapai Rp 500.000.000,-.

b. Hasil penjualan bisnis setiap tahunnya antara $\mathrm{Rp} 300.000 .000$,- sampai paling banyak $\mathrm{Rp}$ 2,5.000.000.000,-.

\section{Pengertian Usaha Menengah}

Usaha menengah adalah usaha ekonomi produktif yang dilakukan orang perseorangan, yang tidak menjadi bagian dari usaha besar, serta memenuhi kriteria usia menengah yang tercantum dalam undang-undang, seperti:

a. Memiliki kekayaan bersih antara 500 juta rupiah hingga maksimal 10 miliar rupiah, selain tanah dan bangunan tempat usaha.

b. Memperoleh hasil penjualan tahunan antara 2,5 miliar rupiah hingga maksimal 50 miliar rupiah (nilai nominal ini bisa berubah sesuai perubahan ekonomi yang diatur dalam Peraturan Presiden).

\section{Indikator Perkembangan Usaha Mikro, Kecil dan Menengah}

Para peneliti (Kim dan Choi 1994, Lee dan Miller 1996, Lou 1999, Miles at all 2000, Hadjimanolis 2000) menganjurkan peningkatan omset penjualan, pertumbuhan tenaga kerja, dan pertumbuhan pelanggan sebagai pengukuran perkembangan usaha. Adapun indikator yang dipakai dalam penelitian ini, antara lain:

\section{Omset Penjualan}

Kata omset berarti jumlah, sedangkan penjualan menjual barang yang bertujuan mencari laba atau pendapatan. Menurut Sutanto (1997:10) Penjualan adalah usaha yang dilakukan manusia untuk menyampaikan barang dan jasa kebutuhan yang telah dihasilkannya kepada mereka yang membutuhkan dengan imbalan yang menurut harga yang telah ditentukan sebelumnya. Sehingga omset penjualan berarti jumlah penghasilan atau laba yang diperoleh dari hasil menjual barang atau jasa dalam kurun waktu tertentu, yang dihitung berdasarkan jumlah uang yang diperoleh. 


\section{Tenaga Kerja}

Tenaga kerja atau man power adalah kelompok penduduk dalam unit kerja. Tenaga kerja terdiri dari angkatan kerja dan bukan angkatan kerja. Angkatan kerja terdiri dari (1) golongan yang bekerja, dan (2) golongan yang menganggur dan mencari pekerjaan. Kelomok bukan angkatan kerja terdiri dari (1) golongan yang bersekolah, (2) golongan yang mengurus rumah tang, (3) golongan lain-lain atau menerima pendapatan. Ketiga golongan tersebut dalam kelompok angkatan kerja ini sewaktu-waktu dapat menawarkan jasa untuk bekerja. Oleh karena itu kelompok ini sering juga dinamakan sebagai potensial labour force.

Adanya pertambahan permintaan perusahaan tenaga kerja bergantung kepada pertambahan permintaan masyarakat akan barang dan jasa yang diproduksi. Permintaan tenaga kerja berkaitan dengan jumlah tenaga kerja yang dibutuhkan oleh perusahaan atau instansi tertentu, permintaan tenaga kerja ini dipengaruhi oleh perubahan tingkat upah dan perubahan faktor-faktor lain yang mempengaruhi permintaan hasil produksi, antara lain naik turunnnya permintaan pasar akan hasil produksi dari perusahaan yang bersangkutan, tercermin melalui besarnya volume produksi, dan harga barang-barang modal yaitu nilai mesin atau alat yang digunakan dalam proses produksi.

\section{Pertumbuhan Pelanggan}

Pertumbuhan pelanggan merupakan dimensi dari kinerja pasar yang diartikan sebagai bagian kinerja pemasaran untuk mengukur prestasi pasar suatu produk.

Kaplan dan Norton (2000: 55) dalam (Sibarani \& Zahara, 2013). menjelaskan mengenai kelompok pengukuran yang terkait di dalam perspektif pelanggan, yaitu:

a. Pangsa pasar, menggambarkan proporsi bisnis yang dijual oleh sebuah unit bisnis di pasar tertentu.

b. Akuisisi pelanggan, mengukur seberapa banyak perusahaan berhasil menarik pelangganpelanggan baru.

c. Retensi pelanggan, mengukur seberapa banyak perusahaan berhasil mempertahankan pelanggan-pelanggan lama.

d. Tingkat kepuasan pelanggan, mengukur seberapa jauh pelanggan merasa puas terhadap layanan perusahaan, berupa umpan balik mengenai seberapa baik perusahaan melaksanakan bisnisnya.

e. Profitabilitas Pelanggan, proses segmentasi pelanggan diupayakan dalam kontribusi profitabilitas dari masing-masing segmen tersebut.

\section{Lembaga Keuangan}

Lembaga Keuangan Syariah (LKS) menurut Dewan Syariah Nasional (DSN) adalah lembaga keuangan yang mengeluarkan produk keuangan syariah dan yang mendapat izin operasional sebagai lembaga keuangan syariah (DSN-MUI, 2003). Definisi ini menegaskan bahwa suatu LKS harus memenuhi dua unsur, yaitu unsur kesesuaian dengan syariah Islam dan unsur legalitas operasi sebagai lembaga keuangan. Unsur kesesuaian suatu LKS dengan syariah Islam secara tersentralisasi diatur oleh DSN, yang diwujudkan dalam berbagai fatwa yang dikeluarkan oleh lembaga tersebut. Adapun unsur legalitas operasi sebagai lembaga keuangan diatur oleh berbagai institusi yang memiliki kewenangan mengeluarkan izin operasi (Yaya, Martawireja, \& Abdurahim, 2009, p. 38).

\section{Pembiayaan}

Dalam arti sempit, pembiayaan dipakai untuk mendefinisikan pendanaan yang dilakukan oleh lembaga keuangan. Pembiayaan secara luas yaitu pendanaan yang diberikan oleh suatu pihak kepada pihak lain untuk mendukung investasi yang telah direncanakan. Pada bank konvesional aktivitas pembiayaan lebih dikenal dengan istilah kredit yaitu penyediaan uang atau tagihan yang 
dapat dipersamakan dengan itu, berdasarkan persetujuan atau kesepakatan pinjam meminjam melunasi utangnya setelah jangka waktu tertentu dengan pemberian bunga.

Pengertian pembiayaan menurut Undang-Undang Republik Indonesia Nomor 21 Tahun 2008 adalah penyediaan dana atau tagihan yang dipersamakan dengan hal itu berupa:

a. Transaksi bagi hasil dalam bentuk mudharabah dan musyarakah.

b. Transaksi sewa-menyewa dalam bentuk ijarah atau sewa beli dalam bentuk ijarah muntahiya bittamlik.

c. Transaksi jual beli dalam bentuk piutang murabahah, salam, dan istishna.

d. Transaksi pinjam meminjam dalam bentuk piutang qardha.

e. Transaksi sewa-menyewa jasa dalam bentuk ijarah untuk transaksi multijasa, berdasarkan persetujuan atau kesepakatan anatara Bank Syariah dan/atau UUS dan pihak lain yang mewajibkan pihak yang dibiayai dan/atau diberi fasilitas dana untuk mengembalikan dana tersebut setelah jangka waktu tertentu dengan imbalan ujrah, tanpa imbalan, atau bagi hasil.

\section{Metode Penelitian}

Penelitian ini menggunakan metode kuantitatif dengan jenis penelitian deskriptif-komparatif. Pengambilan sampel dilakukan dengan metode non-probability sampling jenis proporsive sampling.

\section{Hasil}

Data dikatakan dapat ditolak, apabila nilai signifikan lebih besar 0,05 pada $(\mathrm{P}>0,05)$. Sebaliknya, apabila nilai signifikan lebih kecil dari 0,05 pada $(\mathrm{P}<0,05)$, maka data dikatakan diterima.

Tabel 1. Hasil Uji Hipotesis X1

\begin{tabular}{lc} 
& $\begin{array}{c}\text { Test } \\
\text { Statistics } \\
\text { Omset } \\
\text { Sesudah Pembiayaan - } \\
\text { Omset } \\
\text { Sebelum Pembiayaan }\end{array}$ \\
\hline Penjualan \\
\hline $\begin{array}{l}\text { Asymp. Sig. } \quad(2-.000 \\
\text { tailed) }\end{array}$ \\
$\begin{array}{l}\text { a. Wilcoxon Signed Ranks Test } \\
\text { b. Based on negative ranks. }\end{array}$
\end{tabular}

Dari tabel 1 dapat disimpulkan bahwa nilai Asymp. Sig. (2-tailed) dari variabel omset penjualan (X1) yaitu $<0,05$. Bila taraf kesalahan 0,05 , maka nilai $\mathrm{z}$ tabel $=2,042$. Nilai z hitung $-4,794$ ternyata lebih besar dari -2,042. Menurut (Sugiyono, 2017, p. 137), (nilai (-) tidak diperhitungkan karena harga mutlak), sehingga dapat dikatakan variabel omset penjualan (X1) Ho1 ditolak dan Ha1 diterima. Jadi Terdapat perbedaan yang signifikan pada perkembangan omset penjualan UMKM sebelum dan sesudah memperoleh pembiayaan dari lembaga keuangan syariah. 
Tabel 2. Hasil Uji Hipotesis X2

\section{Test Statistics ${ }^{\mathrm{a}}$}

\begin{tabular}{lcc} 
& $\begin{array}{l}\text { Tenaga Kerja } \\
\text { Pembiayaan } \\
\text { Kerja } \\
\text { Pembiayaan }\end{array}$ & $\begin{array}{r}\text { Sesudah } \\
\text { Tenaga } \\
\text { Sebelum }\end{array}$ \\
\hline$Z$ & $-4.673^{\text {b }}$ \\
$\begin{array}{l}\text { Asymp. } \\
\text { tailed) }\end{array}$ & Sig. & $(2-.000$ \\
\hline
\end{tabular}

a. Wilcoxon Signed Ranks Test

b. Based on negative ranks.

Dari tabel 2 dapat disimpulkan bahwa nilai Asymp. Sig. (2-tailed) dari variabel tenaga kerja (X2) yaitu $<0,05$. Bila taraf kesalahan 0,05 , maka nilai $\mathrm{z}$ tabel $=2,042$. Nilai $\mathrm{z}$ hitung $-4,673$ ternyata lebih besar dari -2,042. Menurut (Sugiyono, 2017, p. 137), (nilai (-) tidak diperhitungkan karena harga mutlak), sehingga dapat dikatakan variabel tenaga kerja (X2) Ho2 ditolak dan Ha2 diterima. Jadi Terdapat perbedaan yang signifikan pada perkembangan tenaga kerja UMKM sebelum dan sesudah memperoleh pembiayaan dari lembaga keuangan syariah.

Tabel 3. Hasil Uji Hipotesis X3

\section{Test Statistics ${ }^{\mathrm{a}}$}

Pelanggan Sesudah

Pembiayaan - Pelanggan

Sebelum Pembiayaan

\begin{tabular}{lc}
\hline $\mathrm{Z}$ & $-4.766^{\mathrm{b}}$ \\
$\begin{array}{l}\text { Asymp. } \\
\text { tailed })\end{array}$ & Sig. $\quad(2-.000$ \\
\hline
\end{tabular}

a. Wilcoxon Signed Ranks Test

b. Based on negative ranks.

Dari tabel 3 dapat disimpulkan bahwa nilai Asymp. Sig. (2-tailed) dari variabel pelanggan (X3) yaitu $<0,05$. Bila taraf kesalahan 0,05 , maka nilai $\mathrm{z}$ tabel $=2,042$. Nilai $\mathrm{z}$ hitung $-4,766$ ternyata lebih besar dari -2,042. Menurut (Sugiyono, 2017, p. 137), (nilai (-) tidak diperhitungkan karena harga mutlak), sehingga dapat dikatakan variabel pelanggan (X3) Ho3 ditolak dan Ha3 diterima. Jadi Terdapat perbedaan yang signifikan pada perkembangan pelanggan UMKM sebelum dan sesudah memperoleh pembiayaan dari lembaga keuangan syariah.

\section{Analisis Perbandingan Antara Perkembangan UMKM Sebelum dan Sesudah Memperoleh Pembiayaan dari Lembaga Keuangan Syariah}

\section{a. Perkembangan Omset Penjualan}

Pada perkembangan omset penjualan dapat dilihat dari nilai $\mathrm{z}$ hitung 4,794 $\geq 2,042$, maka Ho ditolak dan Ha diterima, yang artinya terdapat perbedaan yang signifikan pada perkembangan omset penjualan UMKM sebelum dan sesudah memperoleh pembiayaan dari lembaga keuangan syariah pada pelaku UMKM di sekitar pasar Dayeuhkolot.

Dari tabel coefficient dapat dilihat nilai signifikan sebesar 0,000 dimana nilai signifikan penelitian < 0,05. Maka Ho ditolak dan Ha diterima. Jadi berdasarkan pada hasil pengujian dapat disimpulkan bahwa terdapat perbedaan yang signifikan pada perkembangan omset penjualan UMKM sebelum dan sesudah memperoleh pembiayaan dari lembaga keuangan syariah. Analisis perbandingan perkembangan UMKM sebelum dan sesudah memperoleh 
pembiayaan dari lembaga keuangan syariah pada dimensi omset penjualan mengalami perbedaan yang signifikan pada indikator penganggaran usaha, pangsa pasar, penjualan produk, dan keuntungan usaha.

\section{b. Perkembangan Tenaga Kerja}

Pada perkembangan tenaga kerja dapat dilihat dari nilai $\mathrm{z}$ hitung 4,673 $\geq 2,042$, maka Ho ditolak dan Ha diterima, yang artinya terdapat perbedaan yang signifikan pada perkembangan tenaga kerja UMKM sebelum dan sesudah memperoleh pembiayaan dari lembaga keuangan syariah pada pelaku UMKM di sekitar pasar Dayeuhkolot.

Dari tabel coefficient dapat dilihat nilai signifikan sebesar 0,000 dimana nilai signifikan penelitian < 0,05. Maka Ho ditolak dan Ha diterima. Jadi berdasarkan pada hasil pengujian dapat disimpulkan bahwa terdapat perbedaan yang signifikan pada perkembangan tenaga kerja UMKM sebelum dan sesudah memperoleh pembiayaan dari lembaga keuangan syariah. Analisis perbandingan perkembangan UMKM sebelum dan sesudah memperoleh pembiayaan dari lembaga keuangan syariah pada dimensi tenaga kerja mengalami perbedaan yang signifikan pada indikator fasilitas tenaga kerja, kompetensi tenaga kerja, produktivitas tenaga kerja, dan motivasi tenaga kerja.

\section{c. Perkembangan Pelanggan}

Pada perkembangan tenaga kerja dapat dilihat dari nilai $\mathrm{z}$ hitung 4,766 $\geq 2,042$, maka Ho ditolak dan Ha diterima, yang artinya terdapat perbedaan yang signifikan pada perkembangan pelanggan UMKM sebelum dan sesudah memperoleh pembiayaan dari lembaga keuangan syariah pada pelaku UMKM di sekitar pasar Dayeuhkolot.

Dari tabel coefficient dapat dilihat nilai signifikan sebesar 0,000 dimana nilai signifikan penelitian < 0,05. Maka Ho ditolak dan Ha diterima. Jadi berdasarkan pada hasil pengujian dapat disimpulkan bahwa terdapat perbedaan yang signifikan pada perkembangan pelanggan UMKM sebelum dan sesudah memperoleh pembiayaan dari lembaga keuangan syariah. Analisis perbandingan perkembangan UMKM sebelum dan sesudah memperoleh pembiayaan dari lembaga keuangan syariah pada dimensi pelanggan mengalami perbedaan yang signifikan pada indikator kepuasan pelanggan, loyalitas pelanggan, profitabilitas per segmen pelanggan, layanan terhadap pelanggan, pertumbuhan pelanggan, komplain pelanggan, dan keterikatan pelanggan dengan UMKM.

\section{Simpulan}

Dari hasil penelitian tentang analisis perkembangan usaha mikro, kecil dan menengah (UMKM) sebelum dan sesudah memperoleh pembiayaan dari lembaga keuangan syariah (studi kasus: UMKM di Kabupaten Bandung) dapat disimpulkan bahwa:

1. Ada perbedaan antara omset penjualan sebelum dan sesudah pembiayaaan. Omset penjualan sesudah pembiayaan termasuk dalam kategori sangat baik dibanding dengan omset penjualan sebelum pembiayaan. Ada kenaikan pada omset penjualan sesudah pembiayaan yaitu sebesar $85,21 \%$. UMKM yang menerima pembiayaan dari lembaga keuangan syariah mengalami perkembangan usaha karena omset penjualan sesudah pembiayaan lebih meningkat dari omset penjualan sebelum pembiayaan.

2. Ada perbedaan antara tenaga kerja sebelum dan sesudah pembiayaaan. Omset penjualan sesudah pembiayaan termasuk dalam kategori cukup baik dibanding dengan tenaga kerja sebelum pembiayaan. Ada kenaikan pada tenaga kerja sesudah pembiayaan yaitu sebesar 73,22\%. UMKM yang menerima pembiayaan dari lembaga keuangan syariah mengalami perkembangan 
usaha karena tenaga kerja sesudah pembiayaan lebih baik dari tenaga kerja sebelum pembiayaan.

3. Ada perbedaan antara pelanggan sebelum dan sesudah pembiayaaan. Pelanggan sesudah pembiayaan termasuk dalam kategori cukup baik dibanding dengan pelanggan sebelum pembiayaan. Ada kenaikan pada pelanggan sesudah pembiayaan yaitu sebesar 79,64\%. UMKM yang menerima pembiayaan dari lembaga keuangan syariah mengalami perkembangan usaha karena pelanggan sesudah pembiayaan mengalami pertumbuhan dari pelanggan sebelum pembiayaan.

\section{Referensi}

A, N. (2014). Metode Penelitian dan Statistik. Bandung: PT Remaja Rosdakarya.

BANK JAWA BARAT BANTEN. (2018, Oktober). BANK JAWA BARAT BANTEN. Retrieved from bankbjb.co.id: www.bankbjb.co.id

Karim, A. A. (2010). Bank Islam Analisis Fiqh dan Keuangan. Jakarta: PT Raja Grafindo Persada.

Lestari, S. (2009). Perkembangan dan Strategi Pengembangan Pembiayaan Usaha mikro kecil dan menengah (UMKM). Jurnal Pengkajian Koperasi dan UKM, 4, 118.

Marti, S. (2014). PENGARUH EMPLOYEE ENGAGEMENT DAN EMPLOYEE VALUE PROPOSITION TERHADAP KINERJA .

Muhammad. (2004). Manajemen Dana Bank Syariah. Yogyakarta: Ekonisia..

Mustamu, \& Lewiuci, H. R. (2016). Pengaruh Employee Engagement Terhadap Kinerja Karayawan Pada Perusahaan Keluarga Produsen Senapan Angin. Agora.

Neolaka, A. (2014). Metode Penelitian dan Statistik. Bandung: PT Remaja Rosdakarya.

Muhril. (2014). Kontribusi UMKM terhadap Perekonomian Indonesia.

Sibarani, A., \& Zahara, N. H. (2013). Implementasi Balanced Scorecard sebagai alat pengukur kinerja pada Rumah Sakit Bhayangkara POLDA Bengkulu . Ekombis Review, 84.

Tambunan, T. T. (2002). Usaha Kecil dan Menengah di Indonesia Beberapa Isu Penting,. Jakarta: Salemba Empat.

Undang-undang Nomor 10 Tahun 1998 tentang perubahan Undang-undang Nomor 7 Tahun 1998 tentang Perbankan. (n.d.).

Undang-undang Nomor 21 Tahun 2008 tentang Perbankan Syariah. (n.d.).

Undang-undang Nomor 20 Tahun 2008. (n.d.).

Yaya, R., Martawireja, A. E., \& Abdurahim, A. (2009). Akutansi Perbankan Syariah (Teori dan Praktik Kontempo 